\title{
Construction of Micro-learning Space Based on the Cultivation of Postgraduates' Scientific Research Ability
}

\author{
Chenhu Song \\ Postgraduate Department \\ Northeast Electric Power University \\ Jilin, China
}

\author{
$\mathrm{Na} \mathrm{Li}$ \\ School of Foreign Language \\ Northeast Electric Power University \\ Jilin, China
}

\begin{abstract}
The cultivation of scientific research ability of postgraduate students is significant to improve their scientific and technological innovation ability, pushing forward the progress of science and technology and the development of society. With the increasing number of postgraduate students and the gradual expansion of investment in education in the past decade, more and more studies have studied how to improve the overall quality and ability of scientific research of postgraduates. Due to the ever-increasing concentration on the importance of micro-learning, this paper aims to investigate the problems of the construction of micro-learning space based on the cultivation of postgraduates' scientific research ability.
\end{abstract}

Keywords-micro-learning; micro-learning space; postgradute's scientific research ability

\section{INTRODUCTION}

Postgraduate education is the highest level and stage of education in many countries on a global scale, and because of its high degree of relevance with scientific research, postgraduate students has become an important and vital force in scientific research field. The cultivation of scientific research ability of graduate students is of great significance for the improvement of scientific and technological innovation ability, the progress of science and technology and the development of society. In recent years, with the increased number of graduate students and the gradual expansion of investment in education, more and more scholars and managers of colleges and universities call for the further improvement in the overall scientific research quality and ability of graduate students. How to develop the scientific research ability of graduate students has become a hot issue in higher education [1]

\section{GRADUATE STUDENTS' SCIENTIFIC RESEARCH} ABILITY

Postgraduate research ability refers to the capability to carry out the general intellectual creative activities in various disciplines in order to explore the truth. It mainly includes the following five aspects: collecting and processing ability, logical thinking ability, problem solving ability, literature

Sponsored by Jilin Higher Education Association (JGJX2015C35); The Education Department of Jilin Province (2016056) and writing ability and critical ability. In view of the scientific research ability of graduate students, the research of foreign scholars has been carried out earlier and more deeply. Clark(Clark, B.R.) introduced and compared the graduate education systems in the United States, Britain, France, Germany and Japan comprehensively. When it comes to the cultivation of postgraduates' scientific research ability, he also elaborated on the ways of guidance and the characteristics of training in those countries [2]. Lanser, E.G., from the perspective of the relationship between teachers and students, guided students to think independently, starting the related research activities through the establishment of cooperative relations. S. Delamont and Peluchette demonstrated the effectiveness of the collective guidance to promote the postgraduate students' scientific research ability. Smeby put forward the way of writing papers in order to stimulate and reinforce the students to learn how to deal with problems in a critical way. Nada Dabbagh formed a new approach to investigate the connections of the formal learning, informal learning, and virtual spaces from establishing a personal learning environment. Wendy W. Porter and Graham, from the perspective of studyconsciousness development, pointed a new way to the rejudgment of the facilitation and obstruction of Blended Learning and other new forms of learning in the application of higher education based on the diffusion of innovation theory [3].

\section{DOMESTIC RESEARCH ON POSTGRADUTES'S CULTIVATION AND MICROLEARNING}

On the cultivation of postgraduates' scientific research ability, domestic scholars conducted their researches mainly from the following aspects:

The first is the research on the structure and components of the scientific research ability of postgraduate students. Meng Wanjin made a statistical analysis of the structure of graduate students' scientific research ability and divided them into different levels. He also prioritized the constituent elements of the fundamental scientific research ability for postgraduate students. Based on these previous studies, $\mathrm{Gu}$ Mingyuan, Zhao Yansheng, Xu Keyi and etc. carried out an in-depth study on the detailed factors and structures of 
scientific research ability towards postgraduate students and proposed that control of these critical factors on the formation of the students' ability of scientific research should be strengthened and enhanced.

The second focuses the research on the course teaching of postgraduate students. There have been a lot of discussions on the reform of curriculum system in China, and Li Qisheng believed that the curriculum should be constructed on the basis of knowledge, ability and quality. Pan Baiqi paid more attention to the basic structure of subject, emphasizing on establishing the relationship between vertical and horizontal knowledge system.

The third focuses the research on the methods of stimulating and achieving the potentials in scientific research ability for postgraduates, including the research factors should be carefully considered, like the individual students, instructors and training environment of students. They emphasized the scientific potential of students and gave full importance to the leading role of teachers. At the same time, the course teaching of postgraduate, the practice of scientific research and thesis writing were also stressed in order to cultivate the scientific research ability of postgraduate students. Wang Bonian, Li Hua and other scholars believed that thesis writing was the essential section in scientific research training. It should be the main index to measure and determine the level of scientific research ability.

The forth follows the research on the teaching methods in improving the scientific research ability of postgraduate students. Guo Guichun and Sun Qingzhu advocated diverse applications of teaching methods like seminar teaching, case teaching method and lecture-model teaching so that a diversified and multidimensional teaching modes could be formed in order to cultivate new innovative ability and strengthen the graduate students' ability in theoretical analysis and summary.

It can be seen that the domestic and foreign research results play an important role in the cultivation of graduate students' scientific research ability, but there are still 2 deficiencies in the current research:

There are many problems in domestic study of the Chinese postgraduates' ability of scientific research. While it stresses on macro-description, micro-analyses have been overlooked. Much research emphasis has been put on formal and traditional learning methods while people pay less attention to virtual learning. What's more, theories of argumentation have been neglected while interpretations of learning experience have drawn people's full attention. In particular, integrity of scientific research training and the coordination of its internal elements were seldom mentioned up to now.

Domestic study of postgraduates' scientific research training did not make good use of the internet and digital data in contemporary information-based world. Particularly, the advantages of the information environment did not bring any difference to the research on the rules of the improvement of postgraduates' scientific research ability [4].

\section{CONCLUSION}

Theoretically, research on the construction of micro learning space based on the cultivation of Postgraduates' scientific research ability not only will provide more approaches and strategies for training scientific research ability, enrich and complement the educational theories for postgraduates and offer significant theoretical reference for teaching reform and development of postgraduate education but also serve as a scientific basis for the deepening of postgraduate education. In this sense, research on this micro learning mode has the important guiding significance in the theoretical research of the scientific research ability for postgraduates and the scientific research practice.

And, for its application value, micro-learning space based on the cultivation of postgraduates' scientific research ability can effectively solve many problems in the process of postgraduate students, such as: knowledge internalization, information literacy, frontier tracking in scientific research, and academic writing ability. It will also strengthen the independence and initiative of postgraduate student when they conduct researches so that it provides effective reference for digging deeper into the graduate student scientific research ability and reliable empirical basis for China's postgraduate education reform and the construction of higher education quality assurance system.

\section{REFERENCES}

[1] Giannakos M N, Krogstie J, Aalberg T, et al. Video-based learning ecosystem to support active learning: application to an introductory computer science course[J]. Smart Learning Environments, 2016, 3(1).

[2] Ilomaki L, Paavola S, Lakkala $\mathrm{M}$, et al. Digital competence-an emergent boundary concept for policy and educational research[J]. Education and Information Technologies, 2016, 21(3): 655-679.

[3] Anna Pot, Albert Weideman. Diagnosing academic language ability: An analysis of the Test of Academic Literacy for Postgraduate Students [J]. Language Matters: Studies in the Languages of Africa, 2015, 46(1):22-43

[4] Lindsay R, Breen R, Jenkins A, et al. Academic Research and Teaching Quality: The views of undergraduate and postgraduate students[J]. Studies in Higher Education, 2010, 27(3): 309-327. 